\title{
India and Eastphalia
}

\author{
DAVID P. FIDLER* AND SUMIT GANGULY***
}

\section{INTRODUCTION: ENIGMATIC INDIA}

Much of the attention paid to the growth in the political, economic, and strategic importance of Asia focuses on East and Southeast Asia, with China's rise featuring most prominently in analyses. This symposium reflects this pattern because it predominantly contains articles that explore the potential impact of China's emergence as a great power. ${ }^{1}$ However, examination of the possible development of an international order influenced by Asian power and ideas must also include consideration of the other big, emerging Asian power-India. ${ }^{2}$ This article explores India's complex role in the potential dawning and functioning of an Eastphalian international system.

As other articles in this symposium reveal, China will have a significant impact on international politics and economics in the twenty-

* James Louis Calamaras Professor of Law, Indiana University Maurer School of Law-Bloomington; Director, Indiana University Center on American and Global Security.

** Rabindranath Tagore Professor of Indian Cultures and Civilizations and Professor of Political Science, Indiana University-Bloomington; Director, Indiana University's India Studies Program; Director of Research, Indiana University Center on American and Global Security.

1. See, e.g., Tom Ginsburg, Eastphalia as the Perfection of Westphalia, 17 IND. J. GLOBAL LEGAL STUD. 27 (2010) (concentrating mainly on China's role in the possible emergence of an Eastphalia order); Men Honghua, East Asian Order Formation and SinoJapanese Releations, 17 IND. J. GLOBAL LEGAL STUD. 47 (2010); Yanzhong Huang, Pursuing Health as Foreign Policy: The Case of China, 17 IND. J. GLOBAL LEGAL STUD. 105 (2010); Sung Won Kim, Human Security with an Asian Face? 17 IND. J. GLOBAL LEGAL STUD. 83 (2010) (focusing predominantly on East Asian influences on the future of human security); Chang-fa Lo, Values to be Added to Eastphalia by the Emerging China, 17 IND. J. GLOBAL LEGAL STUD. 13 (2010).

2. See, e.g., Sung Won Kim, David P. Fidler \& Sumit Ganguly, Eastphalia Rising? Asian Influence and the Fate of Human Security, WoRLD POL'Y J., Summer 2009, at 53, 53 (including India in analysis of the possible development of an Eastphalian world order). On India's emergence as a great power, see ARVIND PANAGARIYA, INDIA: THE EMERGING Giant (2008); AShley TEllis, INDiA AS A NEW Global Power: AN ACTION AGENDA for THE UNITED STATES (2005).

Indiana Journal of Global Legal Studies Vol. 17 \#1 (Winter 2010)

(C) Indiana University Maurer School of Law 
first century. But, in many ways, the story of India's rise to putative great power status, and its potential contributions to the nature of an Eastphalian world, is perhaps more interesting and complicated. India is the world's largest democracy and is deeply committed to political tenets, such as the importance of a secular government, peaceful transitions of power after elections, an independent judiciary, a vigorous media and press, and civilian control of the military, that resonate with the democratic and human rights ideals espoused globally by Western powers in North America and Europe. Yet, India equally embraces principles that stand in opposition to the Western-led push for global democratization and its attendant human rights, namely the principles of sovereignty and nonintervention in the domestic affairs of other states. Thus, India is much more of an enigma in the emergence of an Eastphalian world than China.

To make sense of this enigma, our analysis unfolds in five parts. First, we look at features of India's economic and political rise in the past ten to fifteen years in order to give the reader a sense of India's place in the shift of power and influence in international relations toward Asia. ${ }^{3}$

Second, we examine India's commitment to the Five Principles of Peaceful Coexistence as an ordering framework for India's worldview and foreign policy. ${ }^{4}$ In this respect, India walks side-by-side with other Asian countries, including China, which also ground their foreign relations in the Five Principles. ${ }^{5}$

Third, we argue that despite India's increasing geopolitical prominence, Indian leaders have failed to develop consistent and coherent strategies for India in relation to the shifts taking place in world politics and economics. ${ }^{6}$ An Eastphalian system may well be emerging, but India seems, at present, to be drifting without a clear perspective of its strategic objectives and role in this new world order.

Fourth, we argue that India's indecisiveness may combine with massive domestic problems the country faces, such as crippling levels of continuing poverty, to render Indian power and influence increasingly impotent in and irrelevant to the evolution of an Eastphalian world order. ${ }^{7}$ In short, India's day in the Eastphalian sun might be short, leaving the field to China and its rivals to shape and compete over.

3. See infra Part II.

4. See infra Part III.

5. See Ginsburg, supra note 1, at 34; Kim, Fidler \& Ganguly, supra note 2, at 58-59 (both discussing the importance of the Five Principles of Peaceful Coexistence to Asian countries).

6. See infra Part IV.

7. See infra Part V. 
Fifth, we explore whether India could carve a path other than irrelevance, a path that would instead make India the indispensable nation in stabilizing the Eastphalian world. ${ }^{8}$ By "indispensable" we mean the country that becomes the broker for balancing material power and ameliorating ideational differences. In other words, India could bridge East and West in the multipolar world this century will experience and, in the process, play a decisive role in melding the lingering promise of democracy with the stubborn imperative of sovereignty.

\section{INCREDIBLE INDIA}

Prognosticators of world politics often predict that the rise of China and India will contribute significantly to reshaping the structure and dynamics of international affairs. Although China tends to gain more sustained speculation in these geopolitical parlor games, the growing economic, political, and strategic importance of India has not gone unnoticed. India's post-Cold War trajectory of economic growth provides compelling evidence of a country experiencing unprecedented, historymaking shifts in its capabilities and potential material power and global influence. Once enamored with socialist central planning and autarkic economic policies (which left it with a bloated bureaucracy, inefficient industries, and anemic economic development), India has become more economically open, dynamic, and interconnected with world flows of goods, services, and capital. This dramatic change, which occurred in less than a generation, has made India a global economic player as never before in its history.

Politically and strategically, India has also experienced newly earned prominence on the global stage. Not only has India continued to function as a vibrant democracy, with regular and peaceful elections taking place in one of the world's most populous and diverse countries, but it has also become, by virtue of its size, capabilities, and potential, more strategically significant for other great powers, especially the United States and China. The Indo-U.S. civilian nuclear cooperation accord struck in $2007^{9}$ illustrates India's new strategic importance because this deal not only recognized the legitimacy of India's status as a nuclear-weapons state, but also demonstrated the American need to improve security and political ties with India as a hedge against the relative decline in U.S. power as Chinese power and multipolarity looms

8. See infra Part VI.

9. On this accord, see Sumit Ganguly \& Dinshaw Mistry, The Case for the U.S.-India Nuclear Agreement, WORLD POL’Y J., Summer 2006, at 11, 11. 
on the global horizon.

India also has new stature in other political arenas, including multilateral actions to stabilize Afghanistan and prevent Pakistan from imploding, negotiations within the World Trade Organization, and diplomatic efforts to address the threat of climate change. India's relations with Iran also factor into strategies being contemplated in the United States, Europe, and the United Nations (U.N.) concerning how to handle Iran's feared acquisition of the capability to make nuclear weapons. As discussed more in Part III below, India's positions on controversial countries (e.g., Myanmar) and global policy initiatives (e.g., advocacy for the principle of the responsibility to protect) cannot be ignored. Although serious reform of the U.N. Security Council is unlikely to occur, India's argument that it should become a new permanent member of the Council has political plausibility because of the country's increasing significance across the range of pressing issues characterizing contemporary international relations.

These examples of India's waxing importance connect to perceptions that power and influence in world affairs are shifting toward Asia. This shift is not simply about China specifically or East Asia more generally because India, the South Asian giant, adds considerable weight to the phenomenon of Asia's new place in the international system. India is a key component of the potential arrival of Eastphalia, or an Asianinfluenced or Asian-centric world order. In short, India's power and ideas will matter more in international affairs than at any other time since becoming an independent state.

\section{INDEPENDENT INDIA}

Understanding how Indian power and ideas will matter more in world politics requires insight into how India approaches foreign policy and international relations. Certain major themes have historically characterized India's worldview, especially its embrace of the Five Principles of Peaceful Coexistence, leadership in the Non-Aligned Movement, and promotion of the rights, needs, and solidarity of the developing world. Unifying these positions is India's fierce sense of its sovereignty and independence, a feature common in many post-colonial states during the Cold War and particularly robust in Asia. During India's transformation in the post-Cold War period, however, some characteristic themes of Indian foreign policy have been rendered obsolete by epochal events (e.g., India's interest in the Non-Aligned Movement) or become less prominent because of India's growing power and position (e.g., India's conceptualization of the developing world). Despite these significant changes, India has remained firmly committed 
to the Five Principles of Peaceful Coexistence, which continue to be the foundation for India's staunch support for the principles of sovereignty and noninterference in the domestic affairs of other states.

Generally speaking, the nature of Indian foreign policy during the Cold War reflected its position as a poor, weak post-colonial state coming into being in the midst of a dangerous bipolar international system. India's experience as the crown jewel of the British Empire forged in its founding generation of leaders a determination not to allow the new democratic republic to fall under the sway of any other power. Sovereignty, no matter how badly exercised, was the lifeblood of postimperial political, economic, and cultural independence for the peoples of India. Indian leadership did not equate India's survival and growth with close political and economic associations with other democracies aligning themselves against the Soviet Union and the spread of communism.

Thus, India was at the forefront of initiatives that served its need for political space to operate as independently as possible in an international order in which the superpowers tried to restrict the flexibility and options of allies, enemies, and neutrals. Along with China and Burma, India promulgated the Five Principles of Peaceful Coexistence (see box) in 1954 as a bulwark against the dangers of foreign aggression, domination, or meddling in the affairs of vulnerable countries. Realizing that making the Five Principles matter in the Cold War system required some form of alliance, India and other countries formed the Non-Aligned Movement to create more political solidarity around the Principles and their application. Although this movement was really another form of balancing in a balance of power system, it served India's material interests and governing ideas to be in the vanguard of the Movement.

\section{Five Principles of Peaceful Coexistence}

1. Mutual respect for territorial integrity and sovereignty

2. Mutual nonaggression

3. Mutual noninterference in internal affairs

4. Equality and mutual benefit

5. Peaceful coexistence

The Five Principles and the Non-Aligned Movement gave India a platform from which to identify injustices it and other developing countries faced and to articulate demands for changes in international politics and economics to bolster the prospects for most of humanity. Thus, India became a prominent champion of pro-developing country 
initiatives and "called for a global foreign aid regime designed to redistribute the world's wealth, an international trading order that favored the needs of the developing world, and the restructuring of such global institutions as the World Bank and the International Monetary Fund so as to give the weaker states a greater voice." ${ }^{10}$

Conceptually, India's approach supported radical transformations in the way international relations operated in the service of rather conservative principles of world order-sovereignty, equality of states, nonaggression, nonintervention, and cooperation for mutual benefit. This strategy contrasted starkly with the prevailing views of the competing blocs about how to end war and sustain peace-the universal spread of specific types of political and economic systems. The counterintuitiveness of the Indian outlook created dilemmas, especially for the theory and practice of international law. The effort to create new international legal norms and rules related, for example, to global economic justice did not fit well with the overarching emphasis on sovereignty and noninterference in the domestic affairs of other states. "You must give me more of your resources and money, but you have no say whatsoever in how I utilize them" was not particularly compelling logic in terms of how international law and governance mechanisms should function in a system ostensibly based on achieving mutual benefit through cooperation.

The determined emphasis by India and other countries on the principles of sovereignty and noninterference had, of course, more basic objectives in terms of international law, ${ }^{11}$ particularly destroying the vestiges of the discriminatory "standard of civilization" that informed international law in the age of empire ${ }^{12}$ and rooting out rules that favored strong powers, such as the customary international law on foreign direct investment, ${ }^{13}$ norms in the law of the sea (e.g., the breadth of the territorial sea and freedom of resource exploitation on the high seas), ${ }^{14}$ and trade rules that did not recognize the disadvantages developing countries faced..$^{15}$ India, in particular, took a prominent stand against the discrimination and hypocrisy it sensed in the Nuclear

10. Sumit Ganguly, India's Foreign Policy Grows Up, WORLD POL’Y J., Winter 2003-04, at 41,41 .

11. For general analysis on India and international law, see R. P. ANAND, ThE DEVELOPMENT OF MODERN INTERNATIONAL LAW AND INDIA (2005).

12. Gerrit W. Gong, The Standard of Civilization in International Society 90 (1984).

13. David P. Fidler, Revolt Against or From Within the West? TWAIL, the Developing World, and the Future Direction of International Law, 2 CHINESE J. INT'L L. 29, 38-39 (2003).

14. Id.

15. Id. 
Non-Proliferation Treaty (NPT). ${ }^{16}$ India insisted that it would not join the NPT and give up its right to develop nuclear weapons when the NPT privileged existing nuclear weapons states but did not effectively hold them to their NPT disarmament obligations. ${ }^{17}$ A similar sense of discrimination and hypocrisy informed India's antipathy towards the U.N. Security Council's dominance by the Five Permanent Members. ${ }^{18}$

Indian support for the Five Principles also meant that it was not very enthusiastic about the post-Second World War development of international human rights law, which justified the international community intervening in the domestic affairs of states. Unlike other democratic nations, India did not embrace the human rights revolution in international law either as an instrument of power politics (as the United States did against the Soviet Union) or as strategy of a new kind of transnational governance (e.g., as the Europeans did through the European Community and the European Convention on Human Rights). India was not hostile to the political significance of rights because its constitution recognized their importance, ${ }^{19}$ rather, India opposed outside meddling in its domestic affairs by other states and international organizations on the basis of human rights principles. To be sure, part of this opposition stemmed from failures of the Indian government to guarantee rights enshrined in the Indian Constitution and human rights treaties India ratified; but the opposition also flowed from application of the Five Principles. Another consequence of this approach to human rights meant that democratic India would not be in the vanguard, with the United States and European countries, of pressuring other states to improve their human rights records.

Finally, India's experience with armed conflict with, and interference in its territory by, Pakistan and China gave the Five Principles deeper existential meaning for the Indian government and steeled its resolve to protect its territorial and political independence from foreign threats and meddling. Post-colonial India emerged into a dangerous neighborhood, as illustrated by the conventional wars India

16. Treaty on the Non-Proliferation of Nuclear Weapons, opened for signature July 1 , 1968, 21 U.S.T. 483, 729 U.N.T.S. 161. On India's perspective on this treaty, see ASHOK KAPUR, INDIA'S NUCLEAR OPTION: ATOMIC DIPLOMACY AND DECISION-MAKING 211 (1976).

17. Arundhati Ghose, Negotiating the CTBT: India's Security Concerns and Nuclear Disarmament, J. INT'L AFF., Summer 1997, at 239, 256.

18. Dharam Shourie, India Makes a Strong Case for UNSC Reform, HINDUSTAN TIMES (New Delhi), Nov. 13, 2005, available at http://web.archive.org/web/20060709065814/ http://www.hindustantimes.com/news/6640_1544815,001600320005.htm.

19. See InDIA CONST. arts. 12-35 (detailing India's fundamental rights), available at http://india.gov.in/govt/constitutions_india.php. On the Indian Constitution generally, see Granville Austin, Working a Democratic Constitution: The Indian Experience (1999). 
fought with Pakistan (1947-48, 1965, 1971, and 1999) ${ }^{20}$ and China $(1962)^{21}$ and the foreign-supported insurgency and terrorist movements India countered within its territory since the first days of its independence. ${ }^{22}$ These very real threats to its territorial integrity and political survival inform India's hypersensitivity about its sovereignty and independence.

The above description of India's historical support for the Five Principles, the Non-Aligned Movement, and the transformation of the well-being of peoples in developing countries does not, of course, mean that India always followed these tenets and initiatives consistently or coherently during the Cold War. For example, India intervened militarily to stop atrocities in East Pakistan in 1971, leading to the creation of Bangladesh, ${ }^{23}$ and in Sri Lanka in the $1980 \mathrm{~s} .{ }^{24}$ For many in the West, India did not appear nonaligned in terms of its relationship with the Soviet Union, which was more cozy and comfortable than India's prickly-to-hostile attitude toward the United States. Indian intransigence on the NPT was not universally applauded by many in the developing world, who feared that India's stance would lead to nuclear proliferation, which could place developing countries in even more danger. Nevertheless, this background helps illuminate India's fierce protection of its independence and sovereignty and its unwillingness to participate in transformative legal or governance projects that would undermine its and other countries' sovereignty and independence through foreign intervention and interference, however well intentioned. India's relative weakness during the Cold War prevented Indian support for the Five Principles from having a significant impact on the nature of international relations, dominated as they were by the global, ideology-centric superpower conflict.

20. See Sumit Ganguly, Conflict Unending: India-Pakistan Tensions Since 1947 (2001).

21. See Steven A. Hoffmann, India AND the China CRisis (1990).

22. On India's experiences with countering insurgencies, see INDIA AND Counterinsurgency: Lessons LeARNED (Sumit Ganguly \& David P. Fidler eds., 2009); RAJESH RAJAgOpalan, Fighting LIKE A GUERRILla: The INDian ARMY AND COUNTERINSURGENCY (2008); VIVEK CHADHA, LOW INTENSITY CONFLICTS IN INDIA: AN ANALYSIS (2005).

23. See Robert Jackson, South Asian Crisis: India, Pakistan, and Bangladesh (1975).

24. Neil Devotta, Blowback: Linguistic Nationalism, Institutional Decay, and ETHNIC CONFLICT IN SRI LANKA 172-73 (2004). 


\section{INDECISIVE INDIA}

Like many countries, India experienced significant challenges in reorienting its foreign policy after the end of the Cold War. In many respects, India found itself on the losing end of its Cold War bets-the Soviet Union collapsed; socialist-inspired economic planning was discredited; and leading initiatives, such as the New International Economic Order, ${ }^{25}$ to raise the political and economic status of the developing world were dead and buried. In 1991, when India began its market-oriented economic reforms, the prospect that India would be, within a decade, projected as a rising great power was not very plausible. Yet, India achieved this distinction despite being so badly handicapped by many of its Cold War domestic and foreign policies.

The turn-about in India's fortunes resulted from three key changes India undertook after the Cold War ended. The first change involved opening its economy and connecting it more directly with the global marketplace for goods, services, and capital. Through economic reforms, the Indian economy began to obtain eye-catching rates of economic growth that left the old cynicism about the lethargic "Hindu rate of growth" in the dust. ${ }^{26}$

The second major change involved a gradually broadening rapprochement with the United States. India expressed concerns about the United States' emergence as a "hyperpower" in the immediate postCold War period, ${ }^{27}$ but Indian leaders realized that they had to improve relations with Washington because nonalignment no longer made any tactical or strategic sense. U.S. foreign direct investment in India, especially in the outsourcing of services, was part of what was fueling Indian economic growth. Although uncomfortable with the extent of U.S. power and influence, and not on the same page with the United States on many issues, India did not perceive the United States as any kind of existential threat to its survival, political independence, or territorial integrity. In fact, democratically and economically reforming India was not on the Americans' "end of history" agenda to spread democracy, capitalism, and human rights globally in the aftermath of the Cold War. Through steps small (e.g., increasing military-to-military cooperation $^{28}$ ) and large (e.g., the negotiation of the Indo-U.S. civilian

25. See Declaration for the Establishment of a New International Economic Order, G.A. Res. 3201 (S-VI), U.N. Doc. A/RES/S-6/3201 (May 1, 1974).

26. See JAGDish BHAGWATI, INDIA IN TRANSition: FREEING THE ECONOMY 84-98 (1993).

27. Ganguly, supra note 10 , at 44 .

28. See US-Indian Strategic Cooperation into the Twenty-First Century: MoRE THAN WORDS (Sumit Ganguly, Brian Shoup \& Andrew Scobell eds., 2006). 
nuclear accord $\left.{ }^{29}\right)$, India remade its relationship with the United States.

The third change involves India's rethinking of its place and role in the post-Cold War world. Freed from the confines of nonalignment, and increasingly integrated into the global economy, India had to reconsider strategic and political assumptions informing its foreign policy and shaping formulation of its national interest. Increasingly, India began to think and act more like a traditional great power than a weak, poor country trying to buy time and space to find its feet. Its economic reforms and adaptation to better relations with the United States illustrate this shift, as does India's abandonment of transformative schemes to redistribute wealth globally and save the developing world from exploitation. India also began to try to advance its interests and exert its influence in new ways, suggestive of a broadening global perspective on its power. For example, India intensified its diplomatic relations and economic cooperation with Southeast Asia, ${ }^{30}$ China, ${ }^{31}$ the Middle East, ${ }^{32}$ and Africa. ${ }^{33}$

Although India managed to maneuver deftly in the turbulence of the post-Cold War period, its adjustments were borne of painful necessity rather than deliberate, visionary grand strategy. Often overlooked in the self-congratulatory atmosphere of India's rise is the reality that the nature of the post-Cold War system, especially American political and economic quasi-hegemony, provided India with the political space and economic opportunities to change course dramatically. In other words, India's transformation was dependent on which superpower won the Cold War, and, ironically, it was not the superpower the Indians had preferred during the Cold War. India's remarkable economic and diplomatic renaissance largely occurred on the coattails of American power and influence.

This context helps explain why, as American power declines, somewhat rapidly, relative to other great powers, India appears awkwardly indecisive about what it wants to do with its new power and influence. As the center for geopolitics shifts towards Asia, and as Asian powers, such as India and China, increasingly have louder voices, backed by material power, in shaping the course of multilateral cooperation, international law, and global governance, the need for

29. See Ganguly \& Mistry, supra note 9 .

30. See Rajiv Sikri, India's Look East Policy, AsIA-PACIFIC REV., May 2009, at 131, 131 44 .

31. See Amardeep Athwal, China-India Relations: Contemporary Dynamics (2008).

32. See Prithvi Ram Mudiam, India AND the Middle East (1994).

33. See Harry G. Broadman, China and India Go to Africa: New Deals in the Developing World, FOREIGN AFF., Mar.-Apr. 2008, at 95. 
clarity as to what directions India and China want to take international relations increases. In short, what is India's vision for an Eastphalian international system and for its role in that system?

As Ganguly and Pardesi argued, "One of the hallmarks of a major power is that it tries to shape its strategic environment proactively rather than reacting on an ad hoc basis when challenges loom or opportunities arise. Thus far, India has shown little political imagination in shaping its strategic milieu." ${ }^{34}$ India's indecisiveness as the Asian-centric international milieu evolves has many possible sources, but two leading reasons are its continued commitment to the Five Principles of Peaceful Coexistence and the serious material constraints and domestic problems India still confronts. In other words, India has not yet developed either the mindset or the means to think and act as a full-fledged great power. As one commentator put it, India has become a big power, but has not demonstrated it knows how to be a great power. ${ }^{35}$

In terms of India's sustained and strong embrace of the Five Principles, the world has seen demonstrations of this reality in India's determined opposition to the application of the purported principle of the responsibility to protect (R2P) in specific cases, namely in the aftermath of Cyclone Nargis in Myanmar ${ }^{36}$ and the end of the Tamil Tiger insurgency in Sri Lanka. ${ }^{37}$ In both cases, India stood shoulder-toshoulder with China and other Asian countries in publicly opposing any R2P intervention into the domestic affairs of Myanmar and Sri Lanka. Less overtly, India has not severed its economic and political ties with Sudan, ${ }^{38}$ despite the ongoing atrocities in that nation and the indictment of Sudan's president for war crimes by the International Criminal Court (which India has not joined). The reasons for "business as usual" with Sudan relate to India's implementation of the Five Principles and its material interests in Sudanese oil and other economic opportunities. Similarly, India ferociously criticizes any foreign

34. Sumit Ganguly \& Manjeet Pardesi, India Rising: What is New Delhi to Do?, WoRLD POL’Y J., Spring 2007, at 9, 16.

35. Philip Stephens, India Faces a Choice: Is it a Big Power or a Great Power?, FIN. Times, Mar. 19, 2009, available at http://www.ft.com/cms/s/0/92dbb440-14bc-11de-8cd10000779fd2ac.html?nclick_check=1.

36. No Shelter from the Storm: Cyclone in Myanmar, THE ECONOMIST, May 10, 2008, at 78. On the attempted application of the R2P principle to Myanmar after Cyclone Nargis,

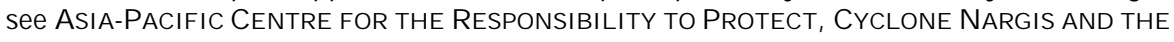
RESPonsibility to Protect (MYANMAR/Burma Briefing No. 2) (2008), http://www.r2pasiapacific.org/documents/Burma_Brief2.pdf.

37. Sri Lanka: UN Rights Council Fails Victims, Human Rights Watch, May 27, 2009, http://www.hrw.org/en/news/2009/05/27/sri-lanka-un-rights-council-fails-victims.

38. See Kim, Fidler \& Ganguly, supra note 2, at 61. 
complaints about its government's behavior within India, particularly concerning human rights concerns related to Indian military and security forces deployed in Kashmir. ${ }^{39}$

Certainly for many in other democratic countries, India's hostility to $\mathrm{R} 2 \mathrm{P}$, refusal to alter political and economic relations with atrocitygenerating regimes, and ironclad denial that any entity or person outside the Indian citizenry has anything to criticize about the Indian government's activities in Kashmir or any other part of its territory is troubling politically, particularly as a vision of how an Asian-centric international order might function. But, India's continued adherence to the Five Principles is only part of the story.

We also have to keep in mind that, despite its rapid rise to prominence, India continues to suffer serious constraints on its material power and what it can do with it. For example, India remains utterly dependent on foreign sources of oil and natural gas, and as its economy continues to grow, this dependence increases. ${ }^{40}$ India's need for oil and natural gas is a geopolitical imperative and vulnerability, and India can scarcely afford to alienate key suppliers of these sources of energy supplies, such as Myanmar, Iran, and Sudan. Conveniently, the Five Principles provide political cover for diplomacy designed to reduce India's vulnerability to energy supply shortages or crises.

In addition, India still lives in a dangerous neighborhood, which is becoming more volatile because of the faltering counterinsurgency campaign in Afghanistan, ${ }^{41}$ the fragility of nuclear-armed Pakistan, ${ }^{42}$ the domestic unrest and repression in Iran, ${ }^{43}$ the mounting signs of state failure in Myanmar, ${ }^{44}$ and the increase in Islamic terrorist

39. Stephens, supra note 35 ("Many see resolution of the Kashmir problem as vital to stable democratic government in Pakistan and, ultimately, to permanent peace in Afghanistan. For a foreign politician to say as much is to invite bitter denunciation for interference in India's internal affairs.").

40. See Manjeet S. Pardesi \& Sumit Ganguly, Energy Security and India's Foreign/Security Policy, in INDIAN ForEIGN POLICY IN A UNIPOLAR WORLD 99 (Harsh Pant ed., 2008).

41. See, e.g., George F. Will, Time to Get Out of Afghanistan, WASH. Post, Sept. 1, 2009, at A12.

42. See, e.g., South Asia Terrorism Portal, Pakistan Assessment 2009, http://satp.org/satporgtp/countries/pakistan/index.htm\# ("Pakistan's descent towards state failure gathered momentum in year 2008. Conflict data and broad governance indicators demonstrate that Pakistan is, today, a nation at war with itself.").

43. For human rights reporting on the situation in Iran, see Amnesty International, Iran's Presidential Election Amid Unrest and Ongoing Human Rights Violations, June 5, 2009, http://www.amnesty.org/en/iran-election-unrest.

44. See ForeignPolicy.com, The Failed State Index 2009, http://www.foreignpolicy.com/ articles/2009/06/22/2009_failed_states_index_interactive_map_and_rankings (ranking Burma as a failed state in critical condition) (last visited Oct. 5, 2009). 
exploitation of ungoverned spaces in Bangladesh. ${ }^{45}$ South Asia constitutes a regional albatross around India's great power aspirations, which limits its freedom of action, both in terms of ideas for engaging countries diplomatically and how it deploys elements of its national power. India's need to address these existing and increasing threats focuses the attention of its leaders on narrow but powerful interests related to national security, leaving reduced inclinations for a broader "vision thing" for an Asian-influenced international order.

The combination of the continued centrality of the Five Principles in Indian foreign policy thinking and material and security constraints on India's power and influence help explain India's indecisiveness with respect to a discernable strategic vision for its role in the emerging Asian-centric international system. Overcoming this indecisiveness will require dramatic changes in either India's commitment to the Five Principles or the material and regional circumstances adversely affecting Indian interests, power, and influence. Otherwise, India may be a player in any emerging Eastphalian order, but it may not leave any distinctive mark on it.

\section{IRRELEVANT INDIA?}

A more sobering possibility is that India emerges as irrelevant to the processes that will shape the shift of power and influence toward Asia. This scenario would unfold if India's massive domestic problems corrode India's global influence and cannibalize its material power. These internal problems may force Indian governments to focus more resources and political capital internally to thwart security threats from terrorist and insurgent groups ${ }^{46}$ reduce still unacceptably high levels of poverty, ${ }^{47}$ stave off deterioration in educational services, ${ }^{48}$ control

45. See, e.g., Ajit Doval, Islamic Terrorism in South Asia and India's Strategic Response, 3 POLICING: J. POL'Y \& PRAC. 63, 66 (2007), available at http://policing.oxfordjournals.org/cgi/content/full/1/1/63 ("The situation in Bangladesh has fast deteriorated after September 11, 2001, [more] than is normally understood. When Pakistan and Afghanistan came under pressure, a good number of terrorists, reportedly with Pak[istani] intelligence support, found Bangladesh as safe haven.”).

46. Perhaps the most serious of these threats comes from the Maoist Naxalite movement. See Jennifer L. Oetken, Counterinsurgency against Naxalites in India, in INDIA AND COUNTERINSURGENCY: LESSONS LEARNED 127, 127-151 (Sumit Ganguly \& David P. Fidler eds., 2009).

47. Andrew Shepherd \& Aasha Kapur Mehta, Chronic Poverty in India: An Introduction, in CHRONIC POVERTY AND DEvelopment POLICY IN INDIA 23, 23 (Aasha Kapur Mehta \& Andrew Shepherd eds., 2006) (noting persistence of "unacceptably high levels of poverty and hunger" in India).

48. Priyanka Bhardwaj, India's Education Mess, Asia Sentinel, Aug. 17, 2009, http://www.asiasentinel.com/index.php?option=com_content\&task=view\&id=2009\&Itemid 
burgeoning communicable and noncommunicable disease problems, ${ }^{49}$ manage the burdens a growing population will impose on rickety and inadequate public health and health care systems, ${ }^{50}$ and address the domestic consequences of climate change, particularly the possibilities of dramatic and adverse alterations in the Himalayan snow melt, seasonality of monsoons, and coastal storm patterns. ${ }^{51}$ In short, India's domestic travails could unravel its ambitions to be a big power, let alone a great power, in the emerging Asian-influenced international system, leaving the field essentially to China and East Asian countries to shape vis-à-vis the United States and European nations.

Domestic political and economic deterioration has gutted great powers throughout history, as illustrated by Rome rotting from within, Czarist Russia imploding into communist revolution, and the Soviet Union disintegrating from the inside out. India's predicament may be even more brittle because its status as a great power is nascent and, in the eyes of many, still tenuous, making this stature even more vulnerable to erosion by worsening domestic problems. ${ }^{52}$ India's list of internal problems is long and growing, obscured sometimes by the flush of national pride and enthusiasm for India's rise in global significance. But, as the saying goes, all politics are ultimately local, and India's desire to be an Asian power that is active, acknowledged, and respected globally may vanish among the slums, civil insecurity, inadequate social services, and poor governance that continues to plague India's future. India's material power vis-à-vis other countries is simply not significant enough at present to make its domestic problems just a domestic matter.

In that context, addressing these domestic problems more robustly will siphon off political and economic resources on a large scale, which may delay or stunt India's maturation as a great political, military, and

$=404$ (noting that "India ranks 102nd of 129 countries, below Kenya and Nicaragua, in the UNESCO 2009 Education for All Development Index.”).

49. See Nat'l Comm'n on Macroeconomics and Health, Burden of Disease in INDIA (2005), available at http://www.whoindia.org/LinkFiles/Commision_on_

Macroeconomic_and_Health_03-NCMH_Burden_of_disease_(29_Sep_2005).pdf

(identifying 17 diseases or conditions that required priority policy attention).

50. See, e.g., Arvind Panagariya, The Crisis in Rural Health Care, Economic Times (India), Jan. 24, 2008, http://www.brookings.edu/opinions/2008/0124_health_care_ panagariya.aspx.

51. Padmaparna Ghosh, How Jairam Ramesh Will Balance Growth and Ecology, LIVEMINT.COM, June 5, 2009, http://www.livemint.com/2009/06/04225504/How-JairamRamesh-will-balance.html (India's Minister of Environment and Forests stating that "[t]he Himalayan glaciers are receding, agricultural yields are stagnating, dry days have increased, [and] patterns of monsoon have become more unpredictable.").

52. China's rise to great power status also faces challenges from its significant domestic problems. 
economic power. India need not become a "failed state" for the domestic drain on its political capital and economic resources to sidetrack its climb to great power status. This internal "black hole" could make India less significant internationally, more vulnerable to outside pressure and threats, and marginalize India's role in the emerging multipolar, Asianoriented world. In this scenario, India's continued support for the Five Principles would not distinguish Indian ideas from those of China or other Asian countries, reducing even further the likelihood of any distinctive Indian contributions to diplomatic endeavors, international law, or global governance.

\section{INDISPENSABLE INDIA?}

Rather than irrelevance, an alternative path for India would be for it to become the power that stabilizes and shapes the shift to an Eastphalian order by acting as the bridge between East and West in the context of the multipolarity this century is expected to experience. India has characteristics that give it, potentially, a unique place at the table of the great powers. Its long-functioning, vibrant democracy gives India political standing with the West that China does not have, nor is expected to have for decades. ${ }^{53}$ India's sensibilities about sovereignty, political and territorial independence, and noninterference give it credibility among those nations, especially in Asia, that have made the Five Principles the basis of their international intercourse. ${ }^{54}$ India's sensitivity to the plight of developing nations would also give it stature with the developing world. Under this perspective, India could emerge as the linchpin power of an Eastphalian order.

To play this role, India would have to develop a strategic vision of its responsibilities as a great power that goes beyond reactive policies to events (no matter how deftly handled) and ritual incantation of the Five Principles. As noted earlier, India has, so far, proved unable or unwilling to think and act proactively and strategically about its power and its ideas in the context of the shifting of world affairs toward Asia. Moving from crisis to crisis and filling the gaps with use of the Five Principles will put India in the perpetual defensive position of adjusting

53. For a detailed analysis of India's support for democracy promotion, see Jan Cartwright, India's Regional and International Support for Democracy: Rhetoric or Reality?, 49 ASIAN SURV. 403 (2009).

54. Japan, as another significant Asian power, is unlikely to be able to play the kind of East-West bridging role envisioned here for India because of its close alliance with the United States and its historical problems with China. More generally, Japan's power and influence in Asia are perceived by experts to be declining. See, e.g., Aurelia George Mulgan, Why Japan Can't Lead, WORLD POL'Y J., Summer 2009, at 101, 110. 
its policies to events shaped by other powers, especially China and the United States. In such a position, the other powers may not be able to ignore India, but they will not have to take it as seriously as if India had developed a strategy and the means to move Eastphalia in specific directions.

India as the linchpin power would have to be able to balance material power among rival states and craft ways in which states can cooperate more effectively on improving human security within countries. In the multipolar nineteenth century, Great Britain acted as the "balancer" in the balance of power, ${ }^{55}$ and it restrained the aggressive interventionism favored by the Holy Alliance of Russia, Prussia, and Austria $^{56}$ while working to address humanitarian problems, such as the slave trade. ${ }^{57}$

India could play a similar set of roles in the emerging Asian-centric, multipolar system. It could stabilize Eastphalia by making sure neither China nor the United States felt sufficiently emboldened or threatened to upset the balance of power. Similarly, India could act as a broker between the universalist sentiments of Western powers, which gravitate towards interventions in the domestic affairs of other states, and the nationalistic preferences of Asian and other non-Western States to emphasize sovereignty and noninterference. The key to melding the promise of democracy and human rights with the stubborn imperative of sovereignty is the ability to demonstrate the benefits of reform and to provide or facilitate functional, workmanlike assistance without raising the stakes of reform to existential threats (e.g., regime change).

India could also show more leadership as the fulcrum of an Eastphalian world by shouldering greater responsibilities and risks and blazing trails that it could help others to follow. Such leadership could be productively demonstrated in crafting approaches to difficult collective action problems associated with globalization, including global health and climate change. Playing this role would require India to be a "first mover" in addressing problems, by unilaterally, bilaterally, or

55. Emerson Niou, Peter C. Ordeshook \& Gregory F. Rose, The Balance of POWER: STABILITY IN INTERNATIONAL SYSTEMS 252 (1989) (commenting on Britain's role as "balancer" in the balance of power).

56. Francis H. Hinsley, Power ANd the Pursuit of Peace: Theory and Practice in THE HistoRy OF RELATIONS BETWEEN STATES 106-08 (1967).

57. Huw Lewis-Jones, The Royal Navy and the Battle to End Slavery, BBC.COM, May 2, 2007, http://www.bbc.co.uk/history/british/abolition/royal_navy_article_01.shtml ("The Royal Navy's role in the suppression of the transoceanic slave trades represents a remarkable episode of sustained humanitarian activity, involving patient diplomacy and problematic wrangling over treaty arrangements, dangerous and exacting naval operations, and intense political debate at home questioning the cost and purpose of the patrols."). 
regionally experimenting with solutions to shared problems. Leadership of this kind would give India more credibility as a potential source of ideas and a problem solver rather than an absolutist adherent to the Five Principles.

However, at this time, India is far from being in any position to be the indispensable power of an Eastphalian system. It has not reached a sufficient level of material power vis-à-vis other states to play the "balancer," and it remains shackled to multiplying domestic problems that will create increasing friction as India tries to move from being a big power to a great power. In addition, India's attitude toward the Five Principle seems inflexible, which, when combined with similar approaches taken by China and other Asian countries, would make Eastphalia a place where new international legal norms and global governance innovations go to die. India also has not demonstrated much in the way of "first mover" leadership because it has been intent to pursue "India first" in its emergence as an Asian power and global player. The slim prospects for India's emergence as the indispensable Eastphalian power leaves the legal and governance possibilities of an Asian-centric, multipolar system shrouded in uncertainty, potentially subject to the harsher politics of an Asianized version of the security dilemma, featuring the United States and China as the main protagonists.

\section{CONCLUSION}

India's increased political and economic significance forms part of the story of the shift in power and influence toward Asia. Thus, India deserves to be analyzed as a factor in the potential emergence of an Asian-centric international system and its impact on international law and global governance. As we have argued, India's role in the possible coming of an Eastphalian order is enigmatic for many reasons, including the paradox of India's commitment to democracy internally and its dedication to strong principles of sovereignty and noninterference internationally. This situation creates confusion and potential conceptual obstacles for Indian development of distinctive contributions to the operation of legal rules and governance mechanisms in Eastphalia. The enigma of India also involves the significant uncertainty whether India will actually overcome external restraints on its material power and freedom of action, as well as the persistent and deepening governance, security, economic, and social problems domestically to emerge as a great power peer with the United States and China. 
Kamal Nath, India's former minister of commerce and industry, captured the growing swagger among Indian elites when he said, "We no longer discuss the future of India. The future is India." ${ }^{58}$ To be sure, the future of any Asian-centric, multipolar international order will be affected by what happens to India because India has reached a level of geopolitical critical mass that has to be reckoned with. But the mantra that the "future is India" complacently obscures that this Indianinfluenced future may take very different forms, with each having its own potential impact on how an Eastphalian world would function and what role international law and global governance would have in this world. Geopolitics is not a Bollywood or Hollywood adventure-India's success in Eastphalia is not written.

58. Kamal Nath, Minister, Commerce \& Indus., Speech at the 30th Anniversary of the U.S.-India Business Council (June 3, 2005), www.indianembassy.org/press_release/ 2005/June/3.htm. 